\title{
Leaf micromorphology in Zea mays L. amylacea from the Lluta Valley (Arica-Chile) with excess boron and salinity
}

\author{
Micromorfología de hoja de Zea mays L. amylacea del valle de Lluta \\ (Arica-Chile) con un exceso de boro y la salinidad \\ Elizabeth Bastías ${ }^{1}$, Luis Tapia ${ }^{1}$, Richard Bustos ${ }^{1}$, Wilson Huanca ${ }^{1}$
}

\begin{abstract}
Micromorphological and anatomical characteristics of the leaves of Zea mays L. amylacea were analyzed using digital images obtained from SEM. Concentrations of $100 \mathrm{mM} \mathrm{NaCl}$ (low salinity, L) or $430 \mathrm{mM} \mathrm{NaCl}$ (high salinity, H) and/or an excess of B supplied as boric acid to obtain $20(334 \mu \mathrm{M})$ and $40(668 \mu \mathrm{M}) \mathrm{mg} \mathrm{B} \mathrm{kg}^{-1}$ were added to the nutrient solution for 20 days. Our results complement other studies of the ecotype amylacea and confirm the high degree of tolerance to salinity and excess boron it shows, especially in the role of xylem vessels in the entry and transport of water and ions and their relation to the regulation of the stomata.

Key words: boron, salinity, Zea mays L. amylacea, micromorphology.
\end{abstract}

\section{RESUMEN}

Se analizaron las características micromorfológicas y anatómicas en la hoja de Zea mays L. amylacea. Las imágenes digitales obtenidas a partir de SEM (microscopia electrónica de barrido) se utilizan con este propósito. Las concentraciones de $100 \mathrm{mM}$ de $\mathrm{NaCl}$ (baja salinidad, $\mathrm{L}$ ) o $430 \mathrm{mM}$ de $\mathrm{NaCl}$ (de alta salinidad, $\mathrm{H}$ ) se utilizaron en el caso de los tratamientos de solución salina,

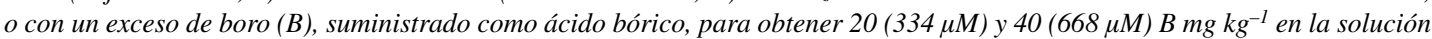
nutritiva durante 20 días. Nuestros resultados complementan otros estudios realizados en el ecotipo amylacea y confirman el alto grado de tolerancia a la salinidad y al exceso de B. Sobre todo, el rol de los vasos xilemáticos en la entrada y el transporte de agua y los iones y su relación con la regulación de los estomas.

Palabras clave: boro, salinidad, Zea mays L. amylacea, micromorfología.

\section{Introduction}

A major cause of the decline in crop production world-wide has been attributed to salt stress (Giri et al., 2003; Al Karaki, 2006). Accumulation of salt in the soil generates a low water potential zone and hinders acquisition of both water and nutrients (Porcel et al., 2006). The cereal crops have been extensively studied to dissect the physiological and genetic basis of salt tolerance and the knowledge gained from such studies may help to develop salttolerant cultivars. The salt tolerance of some crops is essentially sodium exclusion, which limits the entry of sodium into the plants and its transport to the leaves, resulting in a relatively higher $\mathrm{K}^{+} / \mathrm{Na}^{+}$ratio in the plants (Dwivedi et al., 2013). Plant ultrastructural features are strongly modified by the presence of excess salt in the rhizosphere (Miyake et al., 2006; Andrea and Tani, 2009). The ultrastructural alterations due to $\mathrm{NaCl}$ can be attributed to $\mathrm{Na}^{+}$and $\mathrm{Cl}^{-}$toxicity and osmotic imbalance, subsequently leading to oxidative stress (Evelin et al., 2013). Salinity conditions are aggravated by the presence of boron (B) in soils and water in arid and semiarid environments. This the case in the Lluta valley of northern Chile, where elevated levels of B in soils and irrigation water limit local agricultural production to a few landrace crops of this region, which has an annual precipitation less than $1 \mathrm{~mm}$ (Bastías et al., 2004b). Similar conditions occur naturally in many parts of world (Smith et al., 2013). Zea mays L. amylacea is a sweet maize variety well-adapted to the agro-ecological characteristics of the Lluta Valley; the physiological mechanisms of tolerance to high levels of $\mathrm{NaCl}$ and $\mathrm{B}$ in amylacea maize have been studied previously with respect to the salt accumulation capacity of tissues, photosynthetic assimilation and water relations (Bastías et al.,

\footnotetext{
1 Departamento de Producción Agrícola, Facultad de Ciencias Agronómicas, Universidad de Tarapacá, Casilla 6-D, Arica-Chile.

* Corresponding author: ebastias@uta.cl
} 
2004b), as well as root hydraulic conductance (Lo), abundance of aquaporins and ATPase activity (Bastías et al., 2004a; Martínez-Ballesta et al., 2008). Very few studies have examined micromorphological changes induced by salts and B in the leaf epidermis and xylem vessel in the flow and transport of water during abiotic stresses. Digital images obtained by scanning electron microscopy (SEM) were used for this purpose. We analyzed the architecture of vessels and alterations in their organization in young leaves of amylacea as a consequence of high salt and B levels.

\section{Materials and Methods}

\section{Growth conditions and experimental design}

The maize germplasm native to Northern Chile, Zea mays L. amylacea ("lluteño" local variety) was germinated in a mixture of perlite and vermiculite $(1: 1 ; \mathrm{v} / \mathrm{v})$. Seedlings were grown in plastic pots with four plants per pot, and irrigated every two or three days to maintain soil water at field capacity with Hoagland solution containing $20 \mathrm{mM} \mathrm{NO}-\mathrm{N} / \mathrm{L}$ (González-Moro et al., 1997) adjusted to $\mathrm{pH} 5.5$. Placement of maize pots was completely randomized. Plants were grown in a greenhouse with an average day and night temperature of $25 / 18^{\circ} \mathrm{C}$, and a relative humidity of $60 / 70 \%$, respectively. Light intensity was set at $350 \mu \mathrm{mol} \mathrm{m} \mathrm{m}^{-2} \mathrm{~s}^{-1}$ and supplemented with warm-white lamps (Philips SON-T AGRO 400 , Belgium), providing a $14 \mathrm{~h}$-photoperiod. Nutrient solutions were prepared using deionized water; $\mathrm{pH}$, osmotic potential and conductivity were monitored weekly. During the first ten days after germination plants were irrigated with the basic nutrient solution to maintain non-saline growing conditions. Subsequently, when plants showed the third leaf fully expanded, they were exposed to an excess of boron and/or salt for 20 days. The basic nutrient solution without addition of salt (NaCl-0) or boron (B-0) was used as the control solution. This basic nutrient solution was supplemented in a factorial design with 100 $\mathrm{mM} \mathrm{NaCl}$ (Low salinity, L) or $430 \mathrm{mM} \mathrm{NaCl}$ (High salinity, $\mathrm{H}$ ), and with an excess of boron supplied as boric acid to obtain $20(334 \mu \mathrm{M})$ and $40(668 \mu \mathrm{M}) \mathrm{mg} \mathrm{B} \mathrm{kg}^{-1}$ in the nutrient solution. The harvesting of fresh plant material was done between 10:00 and 11:00 A.M.

\section{Preparation of tissue for anatomical studies}

The third leaf of maize plants was sampled and immediately cut into $2-3 \mathrm{~mm}^{2}$ pieces and fixed in $5 \%$ glutaraldehyde in $0.05 \mathrm{M}$ sodium cacodylate, $\mathrm{pH} 7.4$ at room temperature for $48 \mathrm{~h}$. Later the pieces were vacuum-infiltrated in the same fixative several times until sinking. The segments were fixed at $4{ }^{\circ} \mathrm{C}$ in sodium cacodylate buffer for $3 \mathrm{~h}$ in total and washed three times ( $1 \mathrm{~h}$ each). Subsequently, samples were post-fixed in $1 \%$ osmium tetroxide in sodium cacodylate buffer for $2 \mathrm{~h}$. The samples were dehydrated in an ascending series of acetone (30-100\%) and propylene oxide. After dehydratation samples were infiltrated with a series of Araldite mixtures with propylene oxide (Durcupam ACM). Finally, tissues were embedded in $100 \%$ Araldite resin. Sections were cut with an ultramicrotome (Ultratome III, LKB Productor, and Control Unit Type 8802 A). For micromorphological analysis scanning electron microscopy was used; samples were critical point dried in liquid $\mathrm{CO}_{2}$ and coated with gold-Sputter (JEOL JFC 1100). The mounted samples were observed with a JEOL JSM-35C operated at $25 \mathrm{kv}$.

\section{Statistical analysis}

The data were statistically analyzed using analysis of variance (ANOVA) and comparison of means using the SPSS software (SPSS 11.0, 2001). All experiments described were repeated three times independently with six replications each time.

\section{Results}

The effect of salinity and B excess on leaf structure was evaluated by SEM performed on leaf sections of control versus stressed plants. Figure 1 shows that leaf mesophyll in a control plant is crossed in its entirety by numerous nerve which have continuity with the vascular system of the stem. The maize leaf possess numerous ribs, about the same size and oriented in parallel along the leaf, called parallel ribs; these ribs are interconnected by means of transverse ribs of smaller size that form a complex network as seen in Figure 1a. Figure 1b shows the architecture of the vascular bundle forming the central rib with modified cells in its vicinity which are hypodermal sclerenchyma (HSC); these are in contact with both 

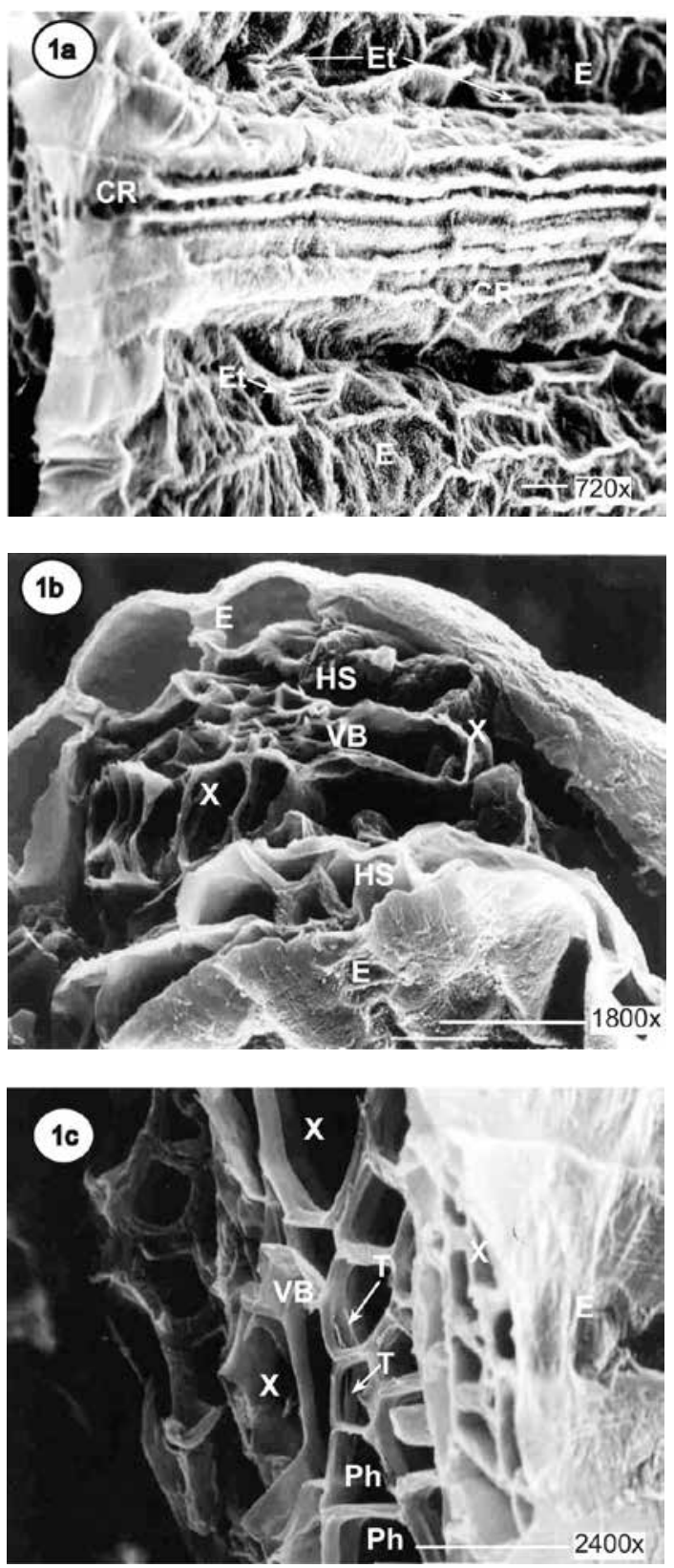

Figure 1. Scanning electron micrograph of a cross section of leaves in control plants of Zea mays L. amylacea. a: general view, leaf cell organization; b-c: typical Kranz anatomy. Labels: Et, stomata; CR, central rib; E, epidermis; HS, hypodermal sclerenchyma; VB, vascular bundle; $\mathrm{X}$, xylem; $\mathrm{T}$, tracheid; $\mathrm{Ph}$, phloem.

upper epidermis and vascular bundle the xylem, as well as between them and the lower epidermis. Also shown is the phloem $(\mathrm{PH})$ rib disposed in parallel (Figures $1 \mathrm{~b}$ and 1c). In Figure 1c the tracheids (TR) of this ecotype can also be observed view scanning electron microscope. There are notable depressions in the tracheids and vessels, as well as the particular relief vessel wall. The application of excess B in non-saline conditions did not cause any alteration in leaf tissue organization. The unique anatomy called Kranz and large vascular bundles (VB), as seen in the cross section of leaf plants treated with the two levels of B (20 and $40 \mathrm{mg} \mathrm{kg}^{-1}$ ) (Figures 2 and 3), do not differ from control plants (Figure 1).
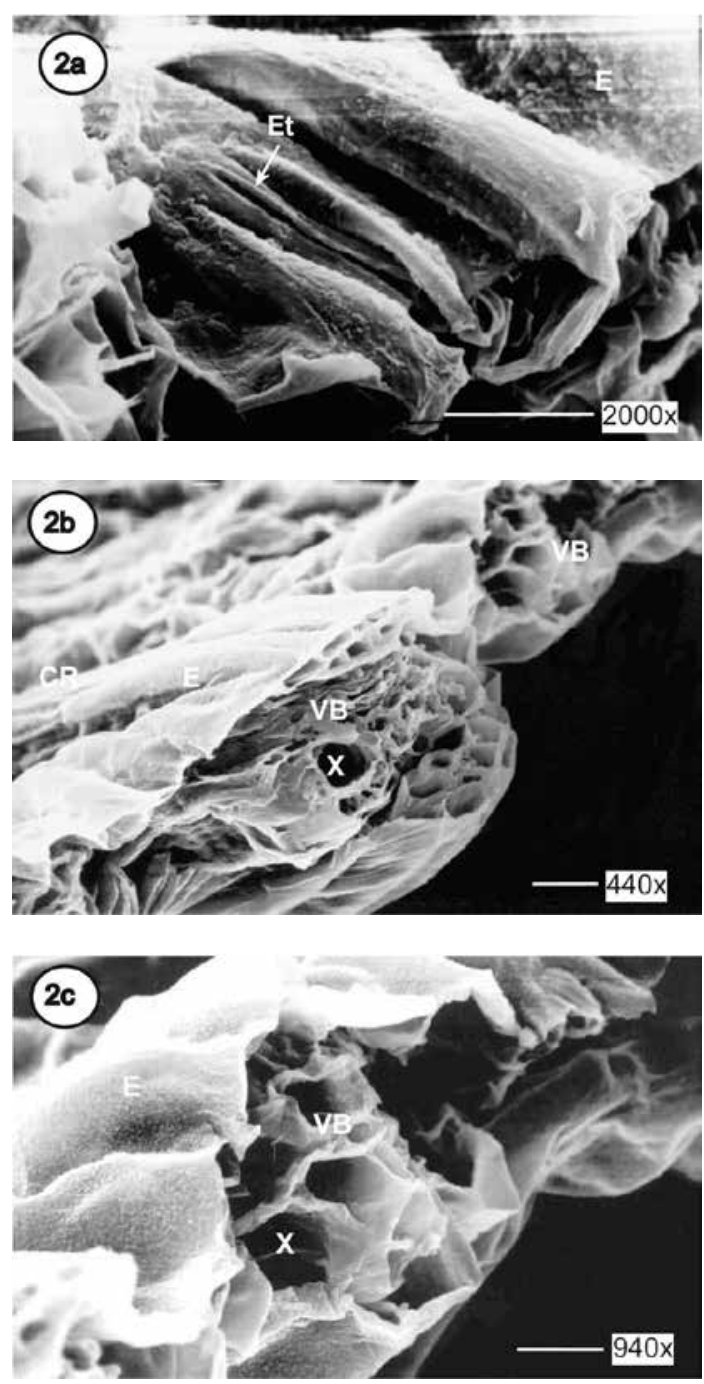

Figure 2. Scan ning electron micrograph of a cross section of leaves treated with B20 (20 mg B kg-1) of Zea mays L. amylacea. a: general view, leaf cell organization; b-c: typical Kranz anatomy. Labels: Et, stomata; CR, central rib; E, epidermis; HS, hypodermal sclerenchyma; VB, vascular bundle; X, xylem; T, tracheid; $\mathrm{Ph}$, phloem. 

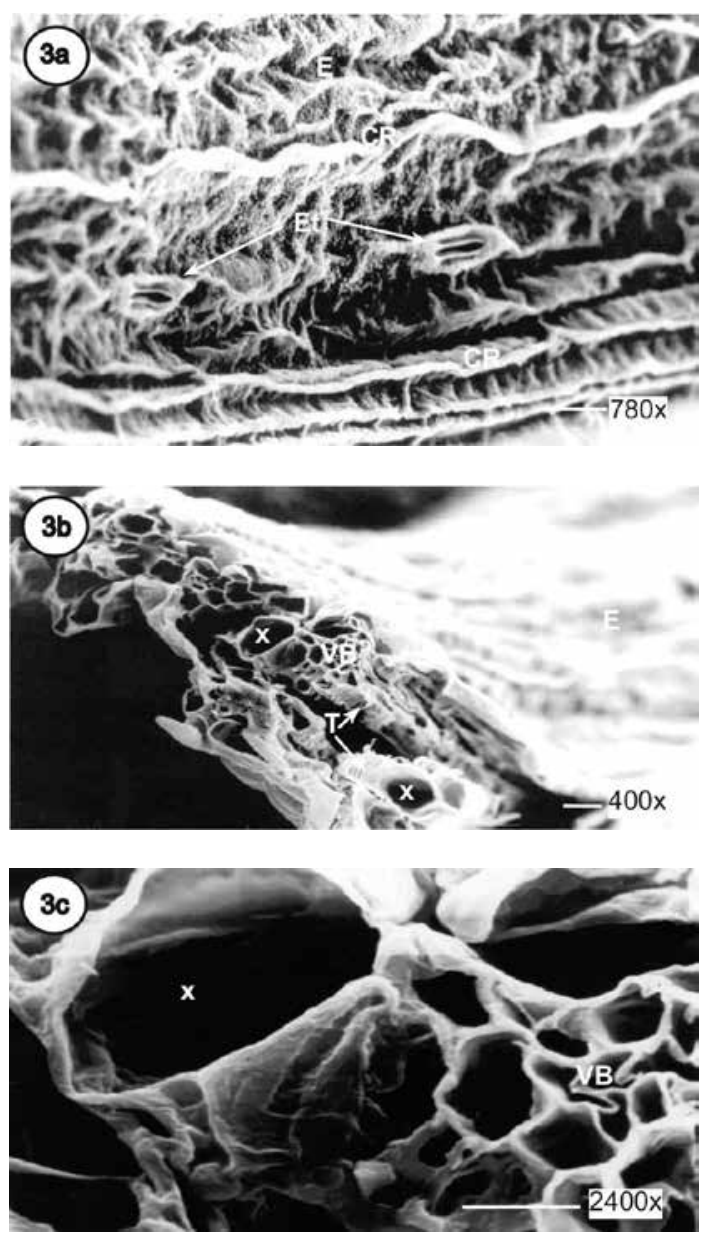

Figure 3. Scanning electron micrograph of a cross section of leaves treated with B40 (40 mg B kg-1) of Zea mays L. amylacea. a: general view, leaf cell organization; b-c: typical Kranz anatomy. Labels: Et, stomata; CR, central rib; E, epidermis; HS, hypodermal sclerenchyma; VB, vascular bundle; X, xylem; T, tracheid; $\mathrm{Ph}$, phloem.

Structural changes in the cells may indicate a tolerance or adaptation to salinity or, conversely, reflect structural damage that would indicate an inability of the species to adapt to salinity.The high salt treatment $(430 \mathrm{mM} \mathrm{NaCl})$ in the absence or presence of $\mathrm{B}$ after 20 days did not alter tissue organization (Figure 4 and 5) or the structure of small, intermediate or large vascular bundles, as shown in the cross section of the blade in electron micrographs obtained by scanning microscopy. No abnormalities were observed with respect to the arrangement and characteristics of the stomata (Figure $4 \mathrm{a}, 5 \mathrm{a}$ and 6 ) or in the large and small vascular bundles (Figures $4 b, 5 c$ and 6 ).
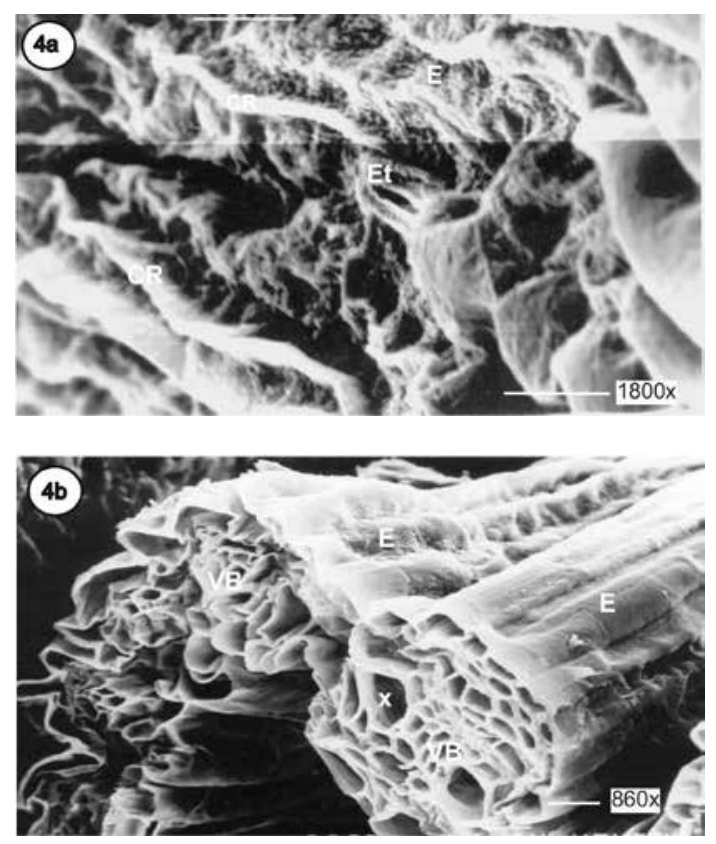

Figure 4. Scanning electron micrograph of a cross section of leaves treated with $\mathrm{NaCl}(430 \mathrm{mM})$ of Zea mays L. amylacea. a: general view, leaf cell organization; b: typical Kranz anatomy. Labels: Et, stomata; CR, central rib; E, epidermis; HS, hypodermal sclerenchyma; VB, vascular bundle; X, xylem; T, tracheid; Ph, phloem.

\section{Discussion}

In the present study, we observed that the application of B mitigates the detrimental effects of $\mathrm{NaCl}$.

The micromorphology of the leaf of amylacea ecotype with application of B and salt presented in Figs. 1-5 showed no altered in leaf tissue architecture under stress. in the presence stomatal nitida well developed and parallel along the leaf, in the typical disposition of monocots (Figures 1, 3, 4 and 5).Thus the optimal structure of the stomata would confirm the ability these to regulate the degree of stomatal aperture under normal and stress conditions as has been shown in several studies of this ecotype (Bastías et al., 2004b; Bastías et al., 2011), even observed an increase the stoma density was significantly greater in plants growing in presence of $\mathrm{NaCl}$ (Carcamo et al., 2012). The amylacea ecotype is able to maintain good water status and transport of water to the aerial part due to the maintenance of the vascular and good structure of stomata to high salinity (Figure 1-5) (Bastías et al., 2004b; Bastías 

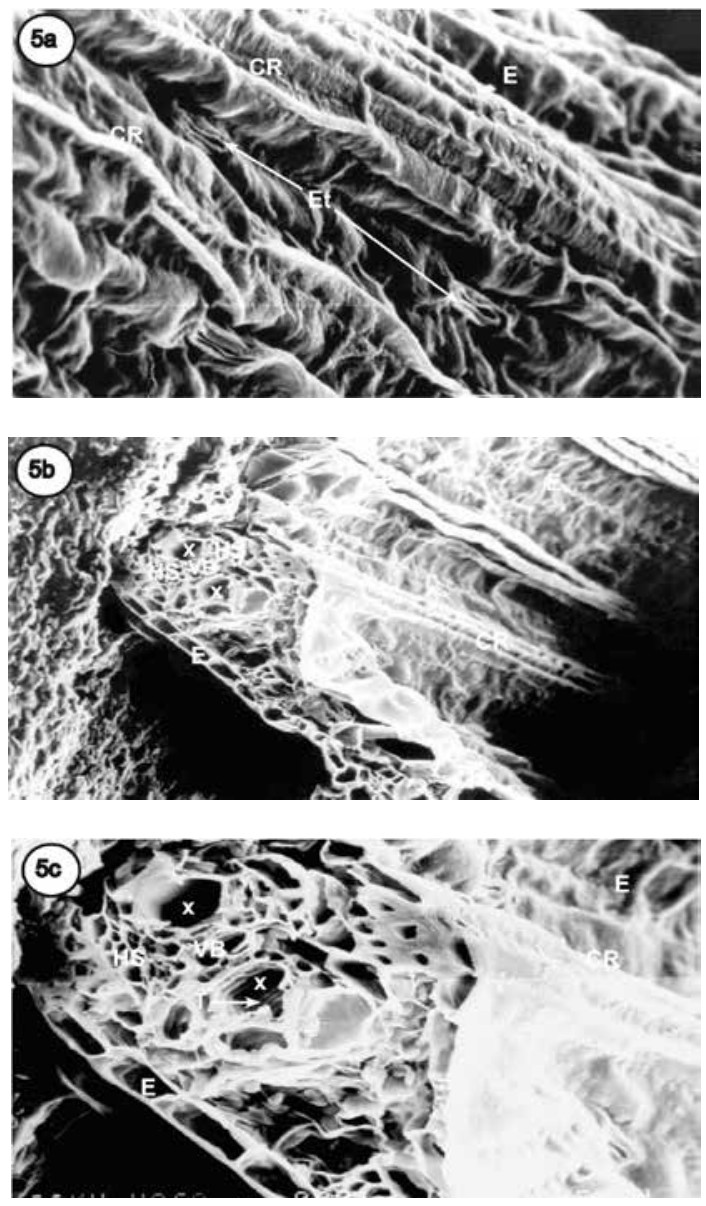

Figure 5. Scanning electron micrograph of a cross section of leaves treated with B20 $\left(20 \mathrm{mg} \mathrm{B} \mathrm{kg}^{-1}\right)+\mathrm{NaCl}(430 \mathrm{mM})$ of Zea mays L. amylacea. a: general view, leaf cell organization; b-c: typical Kranz anatomy. Labels: Et, stomata; CR, central rib; E, epidermis; HS, hypodermal sclerenchyma; VB, vascular bundle; X, xylem; T, tracheid; $\mathrm{Ph}$, phloem.

et al., 2011; Carcamo et al., 2012).In rice plants grown under saline conditions, however, remarkable changes were observed in some regions of vascular tissue, showing almost complete disruption of some intercellular structures such as xylem parenchyma cells and tracheid companion cells, causing decreased water conduction (Rahman et al., 2000). In wheat

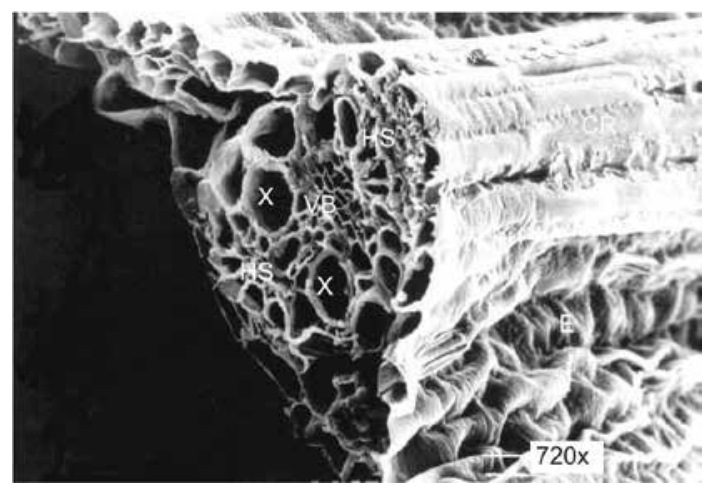

Figure 6. Scanning electron micrograph of a cross section of leaves treated with $\mathrm{B} 40\left(40 \mathrm{mg} \mathrm{B} \mathrm{kg}^{-1}\right)+\mathrm{NaCl}(430 \mathrm{mM})$ of Zea mays L. amylacea. A: general view, leaf cell organization; typical Kranz anatomy. Labels: Et, stomata; CR, central rib; E, epidermis; HS, hypodermal sclerenchyma; VB, vascular bundle; $\mathrm{X}$, xylem; T, tracheid; $\mathrm{Ph}$, phloem.

plants noticeable changes in the vascular tissues of the leaf were also observed due to salinity (120 $\mathrm{mM} \mathrm{NaCl}$ ), reducing its distribution primarily in the leaf (Hu et al., 2005). In the amylacea ecotype, not exudate showed blocking materials such as latex, mucilage, gums, tannins, suberin or amorphous materials,including ion $\mathrm{Na}^{+}$in vascular vessels; similar behavior was found in rose plants (Cohen et al., 2012).

In conclusion, plants did not exhibit major symptoms of toxicity to either $\mathrm{NaCl}$ or boron. This study shows that in amylacea maize the micromorphology of the leaf showed no alterations in tissue and architecture under stress. The leaf anatomical characteristics confirmed the positive effect of B on the growth of amylacea under saline conditions. These properties may be responsible for their ability to withstand growth in this stressful environment.

\section{Acknowledgements}

This study was funded partly by Project UTAMayor 9721-13, CAYBIDE, Project FONDEF D10R1026 and Project FIC P88 Code BIP 301105850 (Arica-Chile). 


\section{Literature Cited}

Al-Karaki, G.N.

2006. Nursery inoculation of tomato with arbuscular mycorrhizal fungi and subsequent performance under irrigation with saline water. Scientia Horticulturae 109: 1-7.

Andrea, B.; Tani, C.

2009. Ultrastructural effects of salinity in Nicotiana bigelovii var. bigelovii callus cells and Allium cepa roots. Caryologia 62: 124-133.

Bastías, E., M.B. González-Moro, C. González-Murua 2004b. Zea mays L. amylacea from the Lluta Valley (AricaChile) tolerates salinity stress when high levels of boron are available. Plant and Soil 267: 73-84.

Bastías, E.; C. Alcaraz-López, I. Bonilla, M.C. Martínez-Ballesta,

L. Bolaños, M. Carvajal

2010. Interactions between salinity and boron toxicity in tomato plants involve apoplastic calcium. Journal of Plant Physiology 167: 54-60.

Bastías, E.; M. Díaz, P. Pacheco, R. Bustos, E. Hurtado 2011. Characterization of maize "lluteño" (Zea mays L. Amylacea type) from northern Chile, tolerant to $\mathrm{NaCl}$ and excess of boron, as an alternative for bio-energy production. Idesia 29: 7-16.

Bastías, E.; N. Fernández-García, M. Carvajal 2004a. Aquaporin functionality in roots of Zea mays in relation to the interactive effects of boron and salinity. Plant Biology 6: 415-421.

Cárcamo, H.; Bustos, R.; Fernández, F.; Bastías, E. 2012. Mitigating effect of salicylic acid in the anatomy of the leaf of Zea mays L. lluteño ecotype from the Lluta Valley (Arica-Chile) under $\mathrm{NaCl}$ stress. Idesia 30: 55-63.

Cohen G., L., Mascarini, Xifreda C.C.

2012. Leaf and stem anatomy and micromorphology in two cut flower cultivars of Rosa hibryda L. ФYTON 81: 199-204.

Dwivedi S.

2012. Bioremediation of heavy metal by algae: current and future perspective. Journal of Advance Laboratory Research in Biology 3: 229-233.
Evelin, H.; Giri, B.; Kapoo, R.

2013. Ultrastructural evidence for AMF mediated salt stress mitigation in Trigonella foenum-graecum. Mycorrhiza 23: 71-86.

Giri, B.; Kapoor, R.; Mukerji, K.G.

2003. Influence of arbuscular mycorrhizal fungi and salinity on growth, biomass, and mineral nutrition of Acacia auriculiformis. Biol Fertil Soils 38: 170-175.

González-Moro, B.; M. Lacuesta, J.M. Becerril, C. GonzálezMurua, A. Muñoz-Rueda.

1997. Glycolate accumulation causes a decrease of photosynthesis by inhibiting RUBISCO activity in maize. Journal of Plant Physiology 150: 388-394.

$\mathrm{Hu}$, Y.; J. Fromm, U. Schmidhalter

2005. Effect of salinity on tissue architecture in expanding wheat leaves. Planta 220: 838-848.

Martínez-Ballesta, M.C.; Bastías, E., C. Zhu, A.R. Schäffner,

B. González-Moro, C. González-Murua C., Carvajal M.

2008. Boric acid and salinity effects on maize roots. Response of aquaporins ZmPIP1 and ZmPIP2, and plasma membrana $\mathrm{H}+$-ATPase, in relation to water and nutrient uptake. Physiology Plant. 132: 479-490.

Miyake, H.; Mitsuya, S.; Rahman, MDS.

2006. Ultrastructural effects of salinity stress in higher plants. In: Rai AK, Takebe T (eds) Abiotic stress tolerance in plants. Springer, The Netherlands, pp. 215-226.

Porcel, R.; Aroca, R.; Ruiz-Lozano, J.M.

2012. Salinity stress alleviation using arbuscular mycorrhizal fungi. A review. Agronomy for Sustainable Development 32: 181-200.

Rahman, M.S.; T. Matsumuro, H. Miyake, Y. Takeoka

2000. Salinity induced ultrastructural alterations in leaf cells of rice (Oryza sativa L.). Plant Production Science 3: $422-429$ 